\title{
Structural and Thermal Analysis of Brake Drum
}

\author{
Shaik Chand Mabhu Subhani ${ }^{1}$ | A.Pavan Kumar $^{2}$ |Dr.D Venkata Rao
}

${ }^{1}$ Asst.professor, Department of Mechanical Engineering, Narasaraopeta Institute of Technology ${ }^{2}$ Assoc.professor, Department of Mechanical Engineering, Narasaraopeta Institute of Technology ${ }^{3}$ Professor and head, Department of Mechanical Engineering, Narasaraopeta Institute of Technology

\section{To Cite this Article}

Shaik Chand Mabhu Subhani, A.Pavan Kumar and Dr.D Venkata Rao, "Structural and Thermal Analysis of Brake Drum", International Journal for Modern Trends in Science and Technology, 6(12): 08-15, 2020.

\section{Article Info}

Received on 06-November-2020, Revised on 18-November-2020, Accepted on 25-November-2020, Published on 29-November-2020.

\section{ABSTRACT}

The brake drum is a specialized brake that uses the concept of friction to decelerate or to stop the vehicle. The deceleration is achieved by the assistance of the friction generated by a set of brake shoes or pads. During the brake operation heat is ejected out this causes damage to the brake. Disc (Rotor) brakes are exposed to large thermal stresses during routine braking and extraordinary thermal stresses during hard braking. To satisfy this condition the drum material should possess a high thermal conductivity, thermal capacity and high strength. The common material used for construction of brake drum is cast iron.

The aim of the project is to design, model a disc. Modeling is done using catia. Structural and Thermal analysis is to be done on the drum brakes using four materials Stainless Steel, gray Cast iron, carbon carbon composite \& aluminum metal matrix. The shoes of this kind of brake are contained within the drum and expand outwards when the brake is applied. Such kind of brakes is used in medium heavy-duty vehicles. Structural analysis is done on the drum brake to validate the strength of the drum brake and thermal analysis is done to analyze the thermal properties. Comparison can be done for deformation; stresses, temperature etc. form the three materials to check which material is best. Catia is a $3 d$ modeling software widely used in the design process. ANSYS is general-purpose finite element analysis (FEA) software package. Finite Element Analysis is a numerical method of deconstructing a complex system into very small pieces (of user-designated size) called elements.

KEYWORDS: rotor brake, CATIA, FEA, thermal analysis, static analysis.

\section{INTRODUCTION}

A brake is a device which is used to bring to rest or slow down a moving body. Safe operation of vehicle demands dependable brakes is required to absorb the kinetic energy of the moving parts or the potential energy of the object being lowered by host when the rate of descent is controlled. The energy absorbed by brakes is dissipated in the form of heat. This heat is dissipated in the surrounding atmosphere to stop the vehicle, The working principle of the drum brakes involves a set of shoes or pads that create friction against a drum connected to the rotating wheel. Brake drum components include the back plate, brake drum, shoe, wheel cylinder, and various springs and pins. Brake drum was invented by Louis Renault in 1902.

He used woven asbestos lining for the brake drum lining as no alternative dissipated heat like the asbestos lining, though Maybach has used a 
less sophisticated brake drum. In the first brake drums, levers and rods or cables operated the shoes mechanically. From the mid-1930's, oil pressure in a small wheel cylinder and pistons operated the brakes, though small vehicles continued with purely mechanical systems for decades. Some designs have two wheel cylinders. The shoes in brake drums wear thinner, and brakes required regular adjustment until the introduction of self-adjusting brake drums in 1950 's. The brake drum is used widely on road vehicles and consists of a drum attached to the rotating wheel.

The drum has an internal machined cylindrical surface. Inside the drum and protected from the environment are two shoes lined with friction material which can be pivoted to make a forced contact with the internal cylindrical surface. A drum brake unit consists of two brake shoes mounted on a stationary backing plate. When the brake pedal is pressed, a hydraulically activated wheel cylinder pushes the shoes out to contact a rotating drum which creates friction and slows the vehicle. As the pedal is released, return springs retract the shoes to their original position.

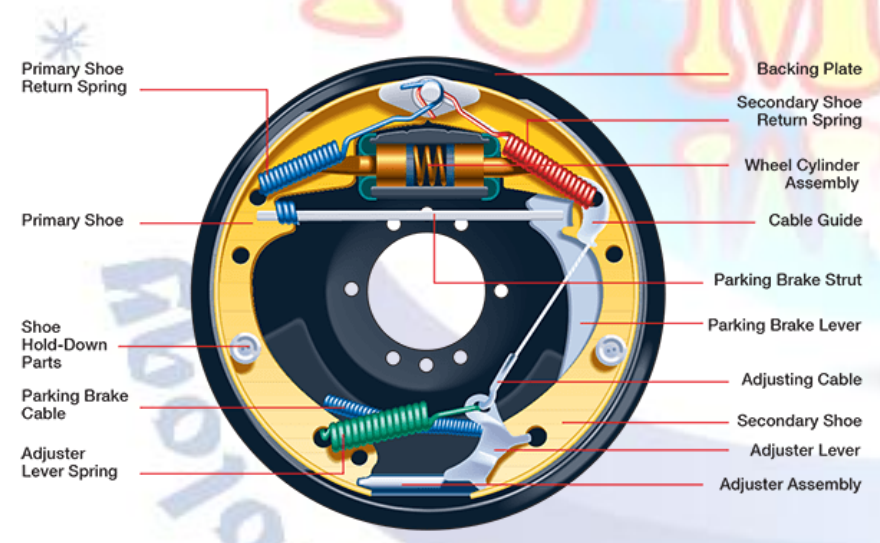

Fig1: Brake Drum Assembly

The important requirements of the brake drum are following

- It should provide a surface having well anti wear qualities.

- It should allow the optimum rate of heat transfer.

- Heat is generated during each brake application and

- It must be dissipated to the atmosphere immediately, because the next brake application would again produce more heat. Any excess heating of brakes would cause the drum to expand resulting in loss of effective pedal travel and fading of brake lining.
- It should have sufficient strength but minimum weight.

- It should be able to be accommodated within the wheel space available.

\subsection{Introduction to Catia}

Catia is the standard in 3D product design, featuring industry-leading productivity tools that promote best practices in design while ensuring compliance with your industry and company standards.

\subsection{Introduction to FEA}

FEA consists of a computer model of a material or design that is stressed and analyzed for specific results. It is used in new product design, and existing product refinement. A company is able to verify a proposed design will be able to perform to the client's specifications prior to manufacturing or construction. Modifying an existing product or structure is utilized to qualify the product or structure for a new service condition. In case of structural failure, FEA may be used to help determine the design modifications to meet the new condition. FEA uses a complex system of points called nodes which make a grid called a mesh. This mesh is programmed to contain the material and structural properties which define how the structure will react to certain loading conditions. Nodes are assigned at a certain density throughout the material depending on the anticipated stress levels of a particular area. In practice, a finite element analysis usually consists of three principal steps.

\subsection{Introduction to ANSYS}

ANSYS is general-purpose finite element analysis (FEA) software package. Finite Element Analysis is a numerical method of deconstructing a complex system into very small pieces (of user-designated size) called elements. The software implements equations that govern the behavior of these elements and solves them all; creating a comprehensive explanation of how the system acts as a whole. These results then can be presented in tabulated or graphical forms. This type of analysis is typically used for the design and optimization of a system far too complex to analyze by hand. Systems that may fit into this category are too 
complex due to their geometry, scale, or governing equations.

\section{Methodology}

Braking systems and brake drums have been reviewed. Static and Thermal analyses on the brake drum on different materials such as aluminium alloy and cast iron have been done. A thermal analysis of different materials such as materials Stainless Steel, grayCast iron, carbon carbon composite\& aluminium metal matrix brake drum will be done as this type of analysis has not been done before.

\section{The objectives of this study are:}

- To model \& meshing the brake drum

- To apply the boundary conditions

- To calculate the maximum temperature, stress, heat flux and strain that is developed on brake drum materials Stainless Steel, grayCast iron, carbon carbon composite\& aluminium metal matrix brake drums.

- To calculate the thermal deformation that is produced due to the application of brake as it exerts an amount of force for the above stated materials.

- To compare all the three results and conclude a best material for the selection of a brake drum.

The steps involved in this methodology are

1. Model design

2. Meshing

3. Material Properties

4. Boundary condition

5. Results \& Discussion

\subsection{THE MODEL DESIGN AND BRAKING} CONDITIONS

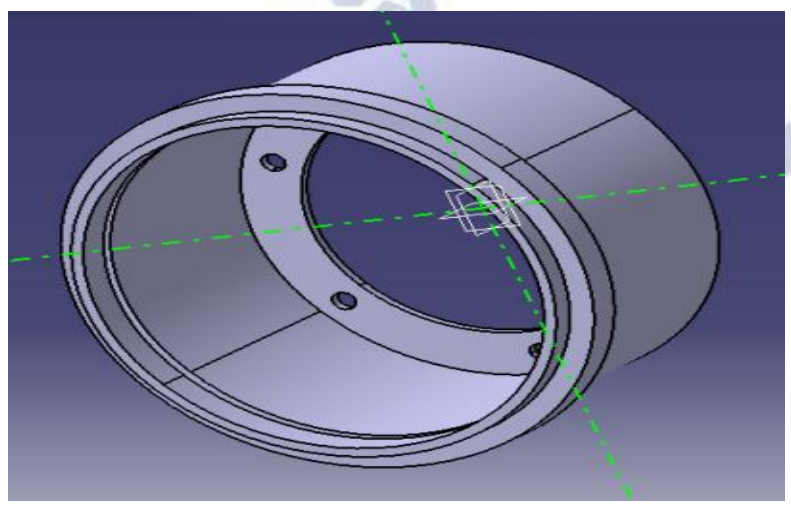

Fig 2: brake drum model in CATIA
A three-dimensional solid with shape and dimensions is modeled in catia. It is imported to ANSYS in igs formate.

\subsection{Meshed Model}

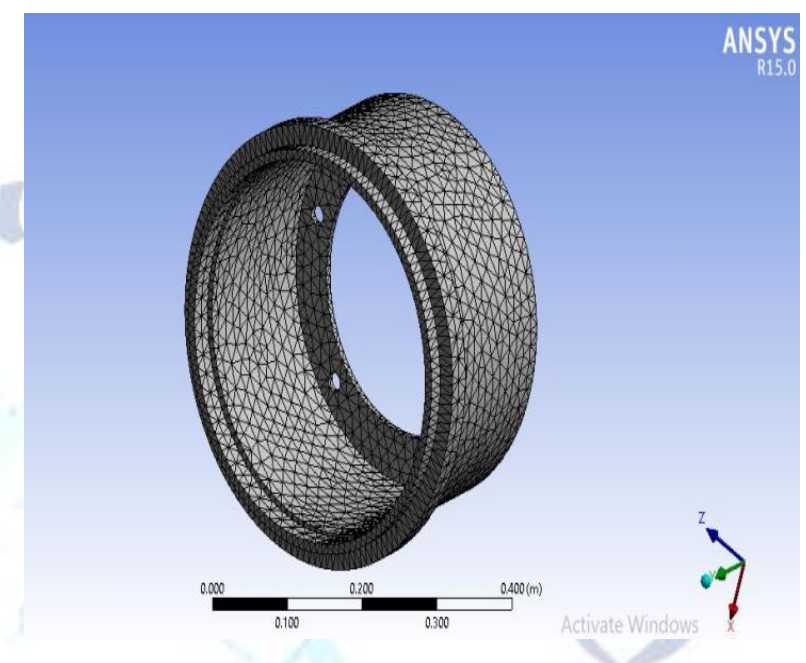

Fig.3 :Meshed Model of Rotor Disc

The elements used for the meshing of the full and ventilated disc are tetrahedral three-dimensional elements with nodes (iso-parametric). In this simulation, the meshing was refined in the contact zone (disc-pad). This is important because in this zone, the temperature varies significantly. Indeed, in this strongly deformed zone, the Thermo mechanical gradients are very high. This is why an accurate account of the contact conditions involve the use of a refined mesh. Three meshes have been tested automatically using an option called convergence in ANSYS Workbench Multi physics.

\subsection{Material Properties}

Table 1: Material properties

\begin{tabular}{|c|c|c|c|c|}
\hline $\begin{array}{c}\text { MATERIAL / } \\
\text { PROPERTY }\end{array}$ & $\begin{array}{c}\text { Stainless } \\
\text { Steel }\end{array}$ & $\begin{array}{c}\text { Gray } \\
\text { Cast } \\
\text { iron }\end{array}$ & $\begin{array}{c}\text { Carbon } \\
\text { carbon } \\
\text { compos } \\
\text { ite }\end{array}$ & $\begin{array}{c}\text { Aluminu } \\
\text { m metal } \\
\text { matrix }\end{array}$ \\
\hline $\begin{array}{c}\text { Density } \\
\text { (kg/m3) }\end{array}$ & 8000 & 7200 & 1800 & 2800 \\
\hline $\begin{array}{c}\text { Young's } \\
\text { modulus } \\
\text { (GPa) }\end{array}$ & 19 & 110 & 95 & 98 \\
\hline Poison's ratio & 0.30 & 0.28 & 0.31 & 0.33 \\
\hline $\begin{array}{c}\text { Thermal } \\
\text { conductivity } \\
\text { (w/m-k) }\end{array}$ & 21.5 & 54.4 & 40 & 15 \\
\hline $\begin{array}{c}\text { Specific heat } \\
\text { (j/kg-k) }\end{array}$ & 500 & 570 & 755 & 850 \\
\hline $\begin{array}{c}\text { Coefficient of } \\
\text { friction }\end{array}$ & 0.22 & 0.2 & 0.3 & 0.3 \\
\hline
\end{tabular}




\section{RESULTS AND DISCUSSION}

\subsection{Static Structural Analysis by using ANSYS} R15

Static structural analysis is a technique used to obtain the deformation, equivalent stresses and the equivalent strains in the brake drum.

The boundary conditions for this analysis are the pressure applied on inner surface of drum is 1.5MPa and fixed at back face

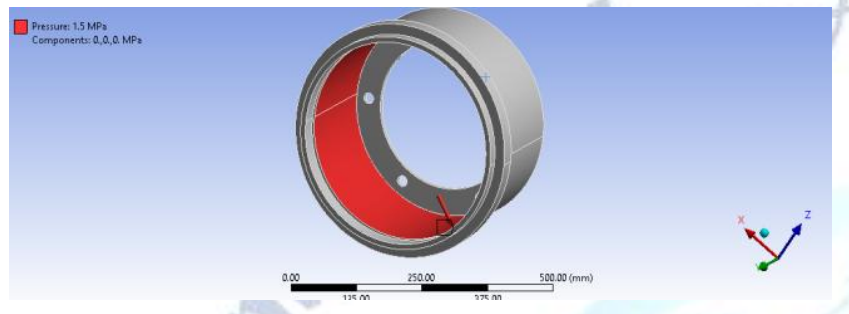

Fig 4: pressure on inner walls of drum

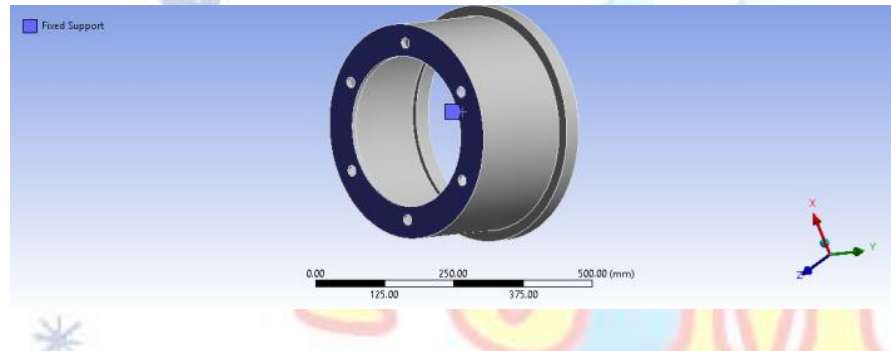

Fig 5: fixed support of drum

3.2 Static Structural Analysis on stainless steel material

Following fig. shows results of total deformation, equivalent stress and strain of stainless steel after analysis.

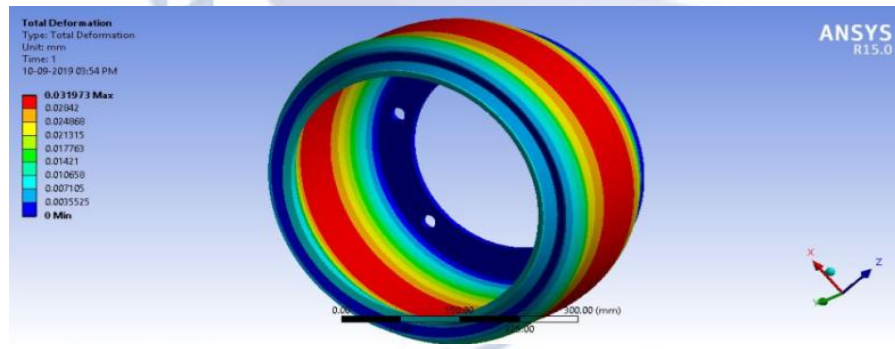

Fig 6: Deformation for stainless steel material brake drum

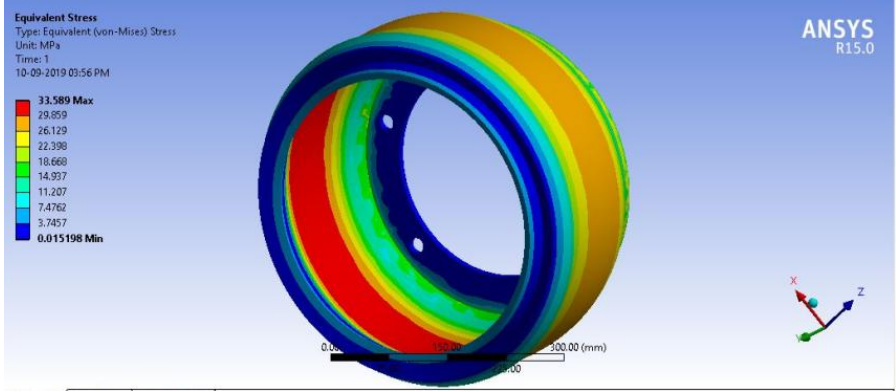

Fig 7: Equivalent stress for stainless steel material brake drum

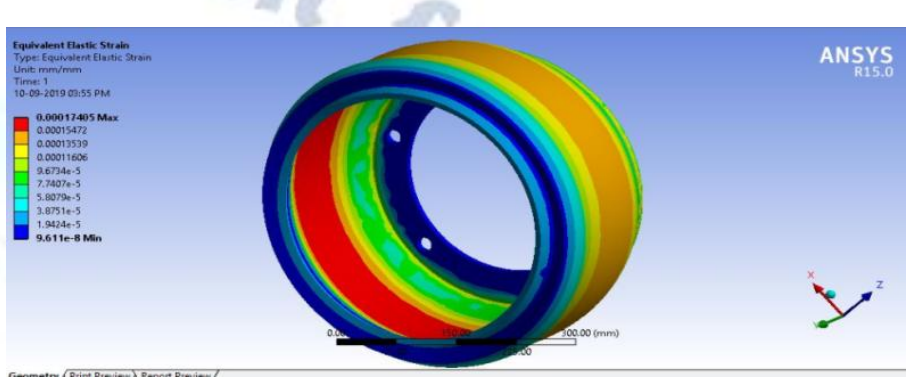

Fig 8: Equivalent elastic strain for stainless steel material brake drum

3.3 Static Structural Analysis on gray cast iron material

Following fig. shows results of total deformation, equivalent stress and strain of gray cast iron after analysis.

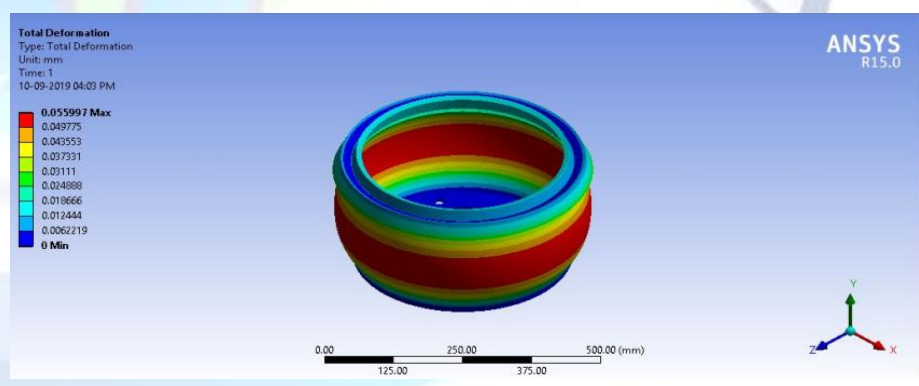

Fig 9: Deformation for gray cast iron material brake drum

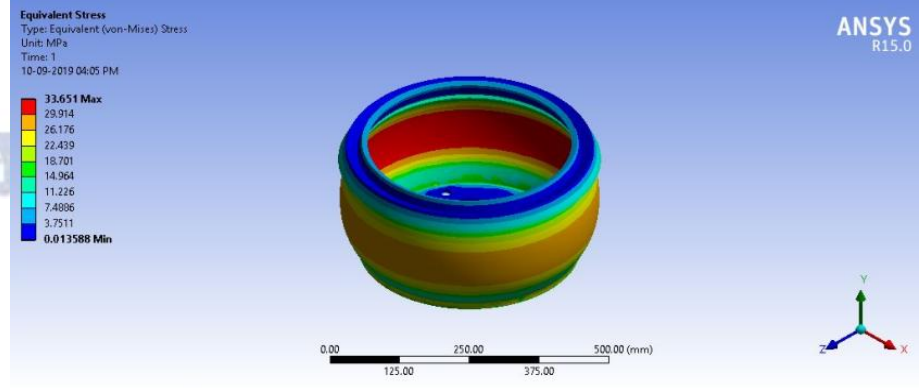

Fig 10: Equivalent stress for gray cast iron material brake drum 


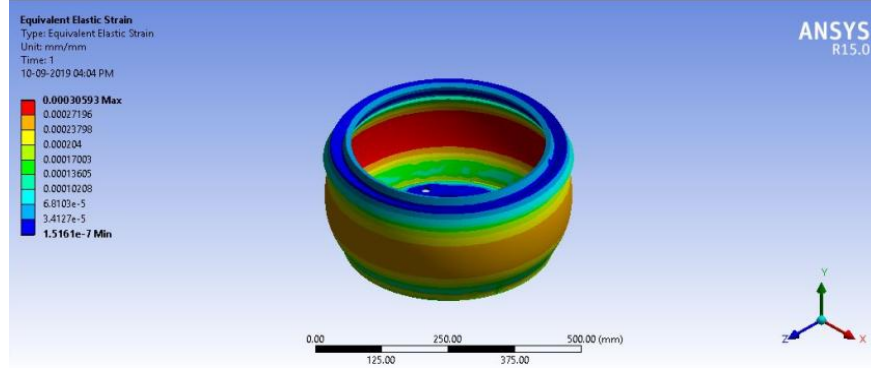

Fig 11: Equivalent elastic strain for gray cast iron material brake drum

3.4 Static Structural Analysis on carbon carbon composite material

Following fig. shows results of total deformation, equivalent stress and strain of carbon carbon composite after analysis.
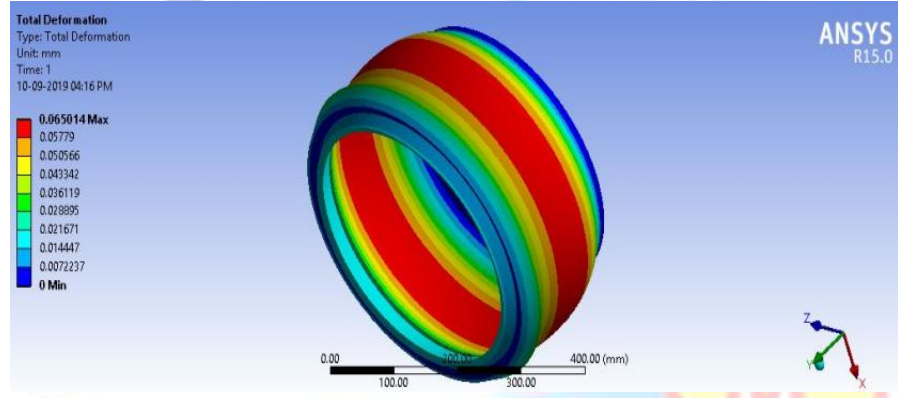

Fig 12: Deformation for carbon carbon composite material brake drum
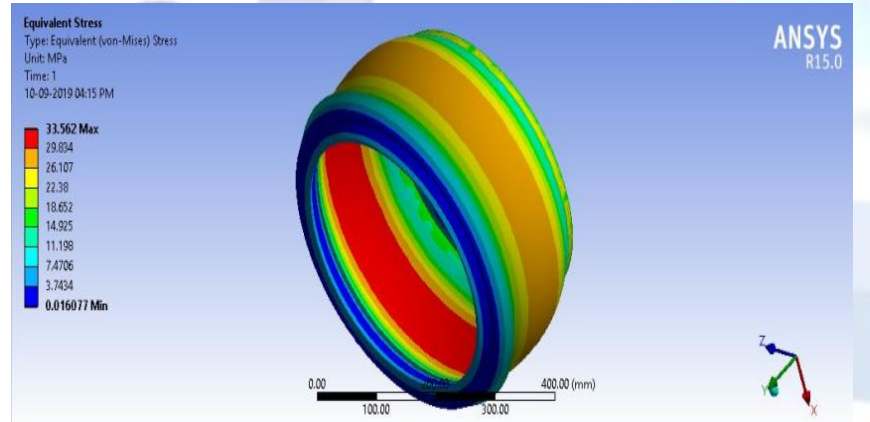

Fig 13: Equivalent stress for carbon carbon composite material brake drum
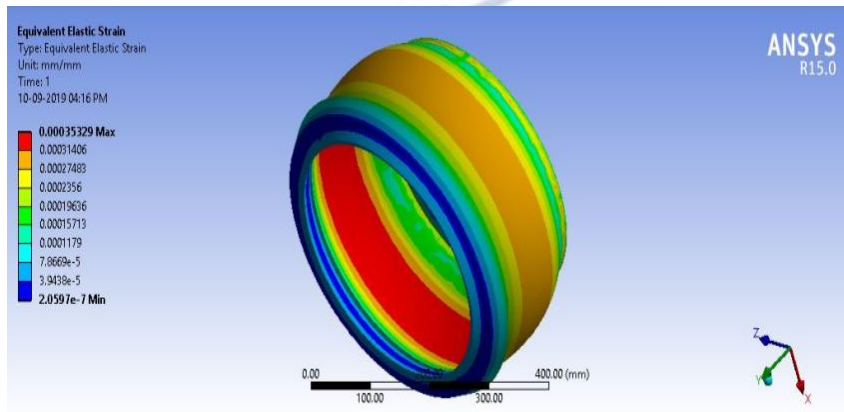

Fig 14: Equivalent elastic strain for carbon carbon composite material brake drum
3.5 Static Structural Analysis on Aluminium metal matrix material

Following fig. shows results of total deformation, equivalent stress and strain of aluminium metal matrix after analysis.

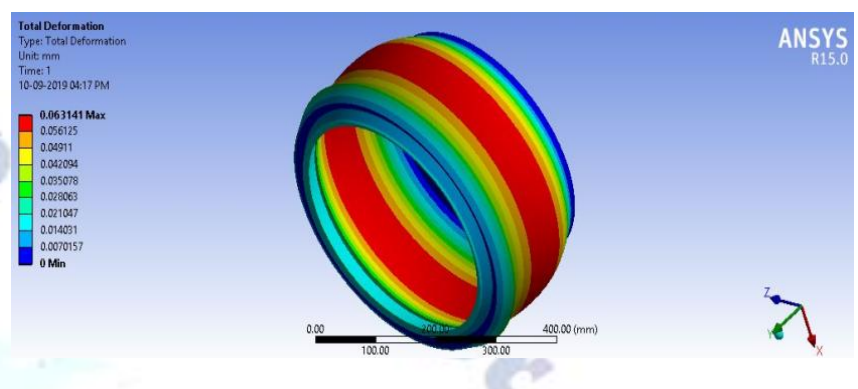

Fig 15: Deformation for aluminium metal matrix material brake drum

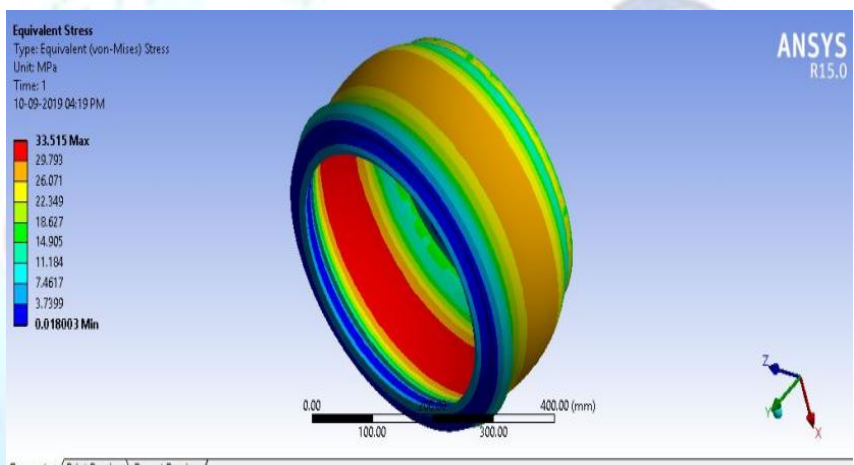

Fig 16: Equivalent stress for aluminium metal matrix material brake drum

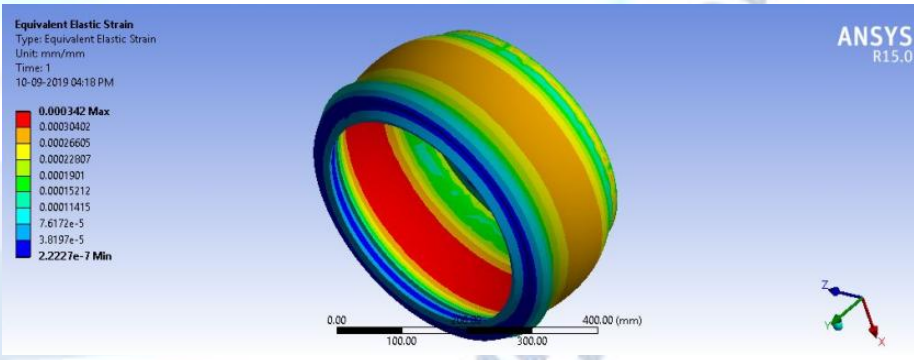

Fig 17: Equivalent elastic strain for aluminium metal matrix material brake drum

\subsection{Thermal analysis by using ANSYS R15}

In acceleration, heat energy of the fuel is converted by the engine into kinetic energy to move the vehicle. In braking, the kinetic energy is converted into heat by means of friction produced between the two mating surface of the brake drum. The amount of friction developed between the two surfaces in contact is independent of the area of the surface in contact. However the magnitude of 
the force of friction or retarding force created between the brake lining and the brake drum depends upon the pressure or force exerted on the shoes by the retarding mechanism and the coefficient for the materials.

\section{Boundary conditions:}

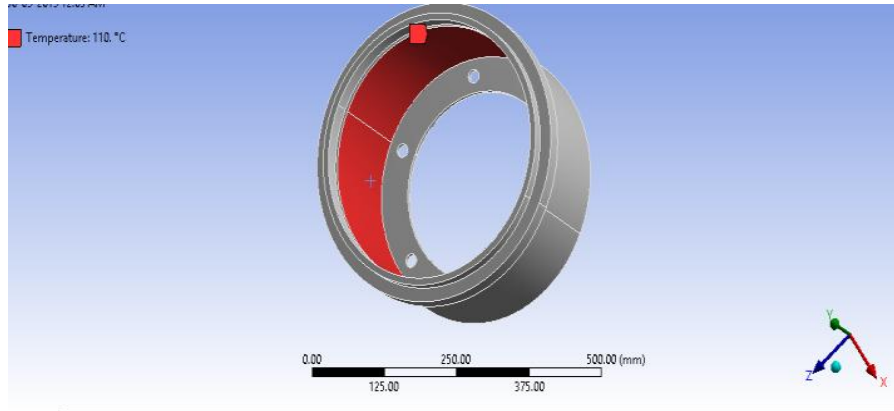

Fig 18: Temperature application in inner side of brake drum

The temperature of $110^{\circ} \mathrm{C}$ applied at inner walls of drum
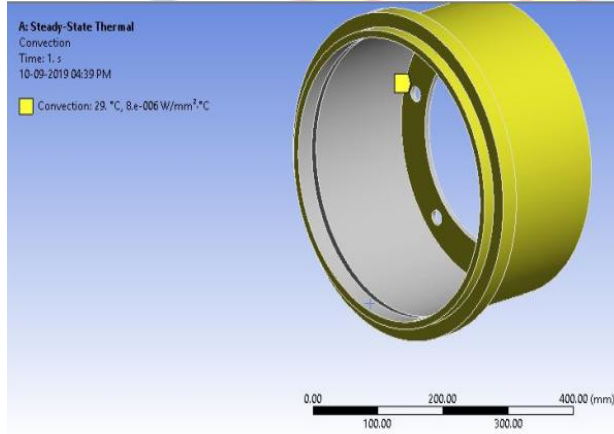

ANSYS

Fig19: The convection application on outer surface

The convection of 8 e- $6 \quad \mathrm{~W} / \mathrm{mm}^{2}{ }^{\circ} \mathrm{C}$ and temperature of $29^{\circ} \mathrm{C}$ applied on outer surface of drum

Thermal analysis is a technique used to obtain temperature distribution and heat flux in the brake drum.

\subsection{Thermal analysis on stainless steel}

Following fig. shows results of obtain temperature distribution and heat flux of stainless steel after analysis.

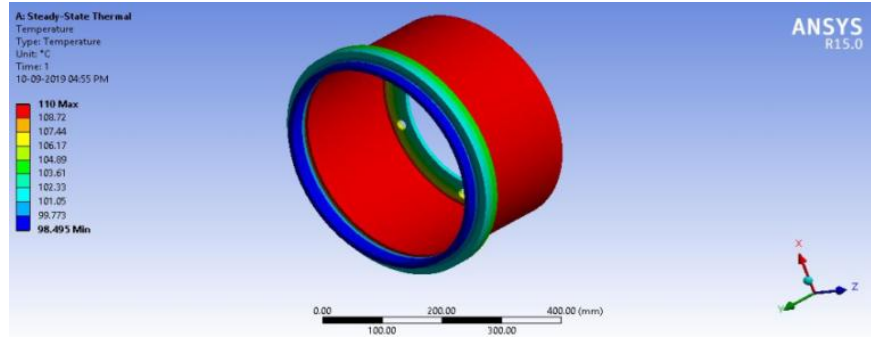

Fig 20: Temperature distribution for stainless steel material

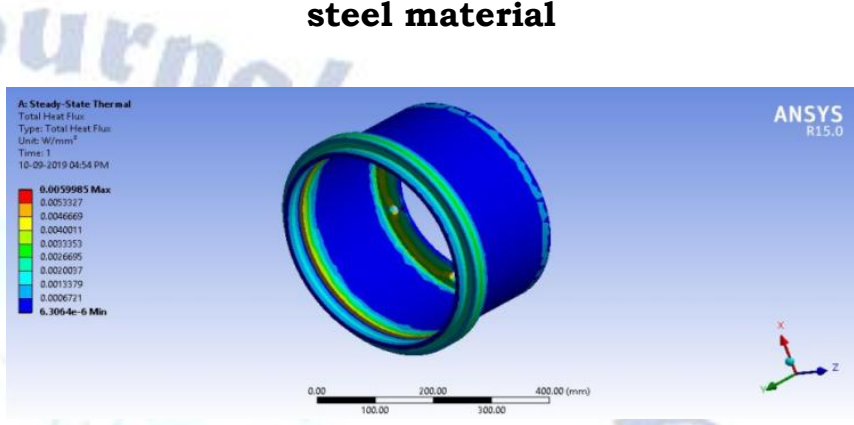

Fig 21: Heat flux for stainless steel material

\subsection{Thermal analysis on gray cats iron}

Following fig. shows results of obtain temperature distribution and heat flux ofgray cast iron after analysis.

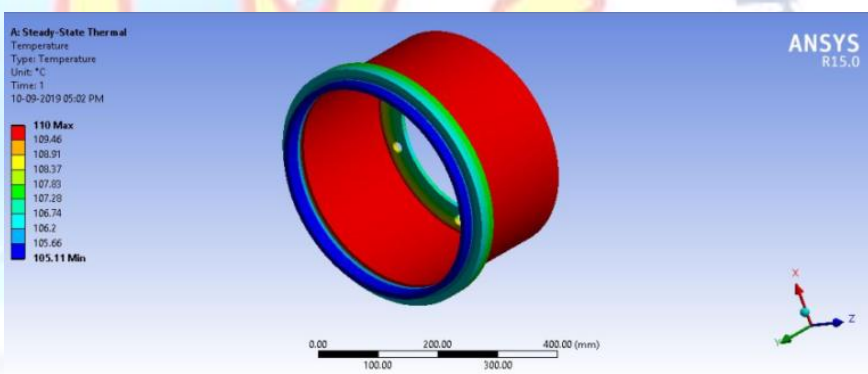

Fig 22: Temperature distribution for gray cast iron material

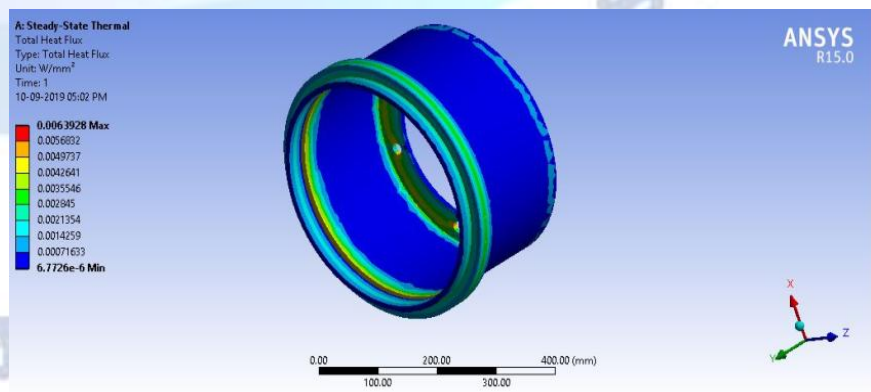

Fig 23: Heat flux for gray cast iron material

\subsection{Thermal analysis on carbon carbon composite}


Following fig. shows results of obtain temperature distribution and heat flux of carbon carbon composite material after analysis

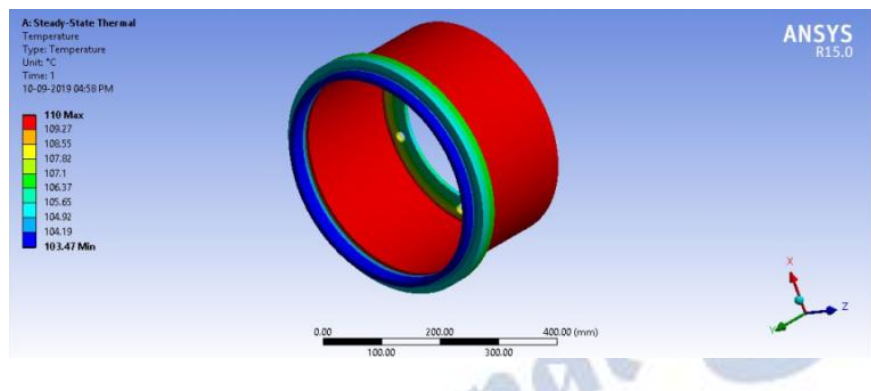

Fig 24: Temperature distribution for carbon carbon composite

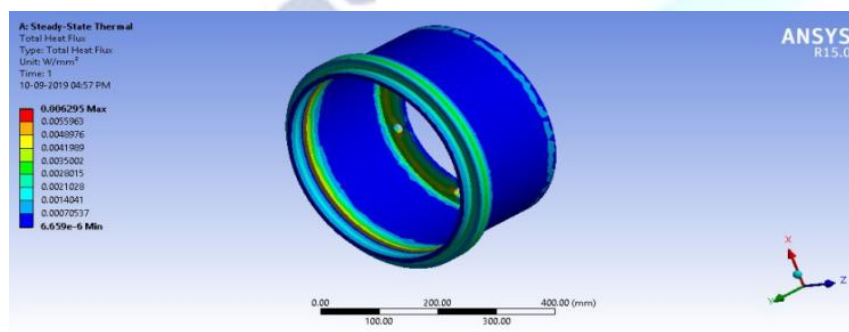

Fig 25: Heat flux for carbon carbon composite material

3.10. Thermal analysis on Aluminium metal matrix

Following fig. shows results of obtain temperature distribution and heat flux of aluminium metal matrix material after analysis

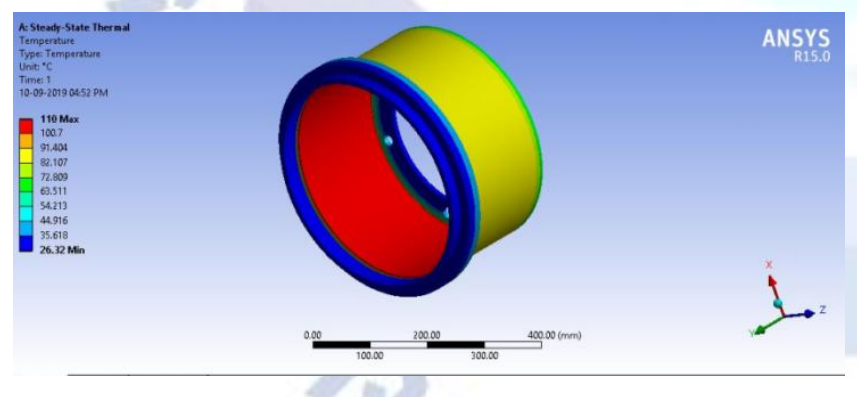

Fig 26: Temperature distribution for aluminium

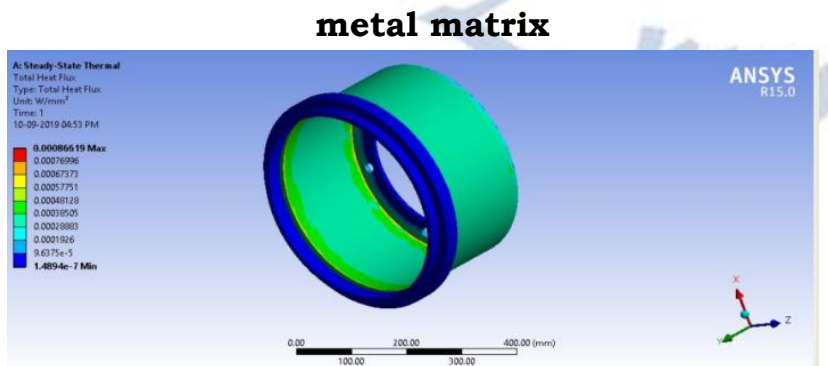

Fig27: Heat flux for aluminium metal matrix material

\section{DISCUSSION}

Table 2: static analysis results

\begin{tabular}{|c|c|c|c|}
\hline $\begin{array}{c}\text { RESULT } \\
\mathbf{S}\end{array}$ & $\begin{array}{c}\text { Total } \\
\text { deformat } \\
\text { ion(mm) }\end{array}$ & $\begin{array}{c}\text { Equivalen } \\
\text { t elastic } \\
\text { strain } \\
\text { mm/mm }\end{array}$ & $\begin{array}{c}\text { Equivalent } \\
\text { elastic } \\
\text { stress(MPa) }\end{array}$ \\
\hline $\begin{array}{c}\text { Stainless } \\
\text { steel }\end{array}$ & 0.031973 & $\begin{array}{c}0.0001740 \\
5\end{array}$ & 33.589 \\
\hline $\begin{array}{c}\text { Gray cast } \\
\text { iron }\end{array}$ & 0.055997 & $\begin{array}{c}0.0003059 \\
3\end{array}$ & 33.651 \\
\hline $\begin{array}{c}\text { Aluminiu } \\
\text { m metal } \\
\text { matrix }\end{array}$ & 0.063141 & 0.000342 & 33.515 \\
\hline $\begin{array}{c}\text { Carbon } \\
\text { carbon } \\
\text { composit } \\
\text { e }\end{array}$ & 0.065014 & 0.0003532 & 9 \\
\hline \multicolumn{2}{|c|}{} & 93.562 \\
\hline
\end{tabular}

Table 3: Thermal analysis results

\begin{tabular}{|c|c|c|c|}
\hline \multirow{2}{*}{ RESULTS } & \multicolumn{2}{|c|}{ Temperature $^{\mathbf{0}} \mathbf{C}$} & \multirow{2}{*}{$\begin{array}{c}\text { Heat flux } \\
\mathbf{w} / \mathbf{m m}^{2}\end{array}$} \\
\cline { 2 - 3 } & $\mathbf{m i n}$ & $\mathbf{m a x}$ & 0.0059985 \\
\hline $\begin{array}{c}\text { Stainless } \\
\text { steel }\end{array}$ & 98.495 & 110 & 0.0063928 \\
\hline $\begin{array}{c}\text { Gray cast } \\
\text { iron }\end{array}$ & 105.11 & 110 & 0.0008619 \\
\hline $\begin{array}{c}\text { Aluminium } \\
\text { metal } \\
\text { matrix }\end{array}$ & 26.32 & 110 & 0.006295 \\
\hline $\begin{array}{c}\text { Carbon } \\
\text { carbon } \\
\text { composite }\end{array}$ & 103.4 & 110 & \\
\hline
\end{tabular}

\section{CONCLUSION}

The static and thermo analysis of brake drum in brake applications has been per-formed. The present study can provide a useful de-sign tool and improve the brake performance of Drum brake system. The values obtained from the analysis are less than their allowable values. Hence the brake design is safe based on the strength and rigidity criteria.

The use of these kinds of materials in brake drum manufacturing provides a range of heat flow values. This range of values is useful in the selection of material comparing with these two materials in different applications. The aluminium metal matrix have low heat flux when compared with the others and minimum temperature also. Although the deformation is high when compared 
with the stainless steel It is observed that the stainless steel has low deformation and low strain which can provide better brake performance than others from deformation point of view whereas gray cast iron has higher from stress point of view.

\section{REFERENCES}

[1] Ramesha.D.K et al - "Temperature distribution analysis of aluminum alloy and cast iron brake drum using Ansys" an International Journal of Emerging trends in Engineering and Development, ISSN 2249-6149, Issue 2,Vol.3 in April 2012.

[2] Nurulhuda Binti Khalid - Thermal stress analysis on brake drum (simulation) - Mechanical Engineering (Thermal-Fluid) of the Kolej University Technical Kebangsaan, Malaysia, in November 2005.

[3] Ray W. Murphy et al - Summary final report on "Bus, truck, tractor/trailer braking system performance" - Contract FH-11-7290 Highway Safety Research Institute-The University of Michigan-Ann Arbor, January 1970.

[4] W. S. Chung, S. P. Jung and T. W. Park, Numerical analysis method to estimate thermal deformation of a ventilated disc for automotives, Journal of Mechanical Science and Technology, 24 (11) (2010) 2189-2195.

[5] F. Talati and S. Jalalifar, Analysis of heat conduction in a disc brake system, Heat Mass Transfer, 45 (2009) 1047-1059.

[6] J. T. Kim and B. J. Baek, A numerical study of thermal performace in ventilated disk brake, Journal of the Korean Society of Tribologists \& Lubrication Engineers, 17 (5) (2001) 358-364.

[7] Y. Choi, J. W. Choi, H. M. Kim and Y. W. Seo, Thermal dissipation performance of the ventilated brake disc having helical grooved vent, Journal of the Korean Society of Precision Engineering, 21 (3) (2004) 117-123.

[8] Esmail M.A. Mokheimer, "Performance of annular fins with different profiles subject to variable heat transfer coefficient", International Journal of Heat and Mass Transfer, Vol. 45, pp 3631-364, 2002.
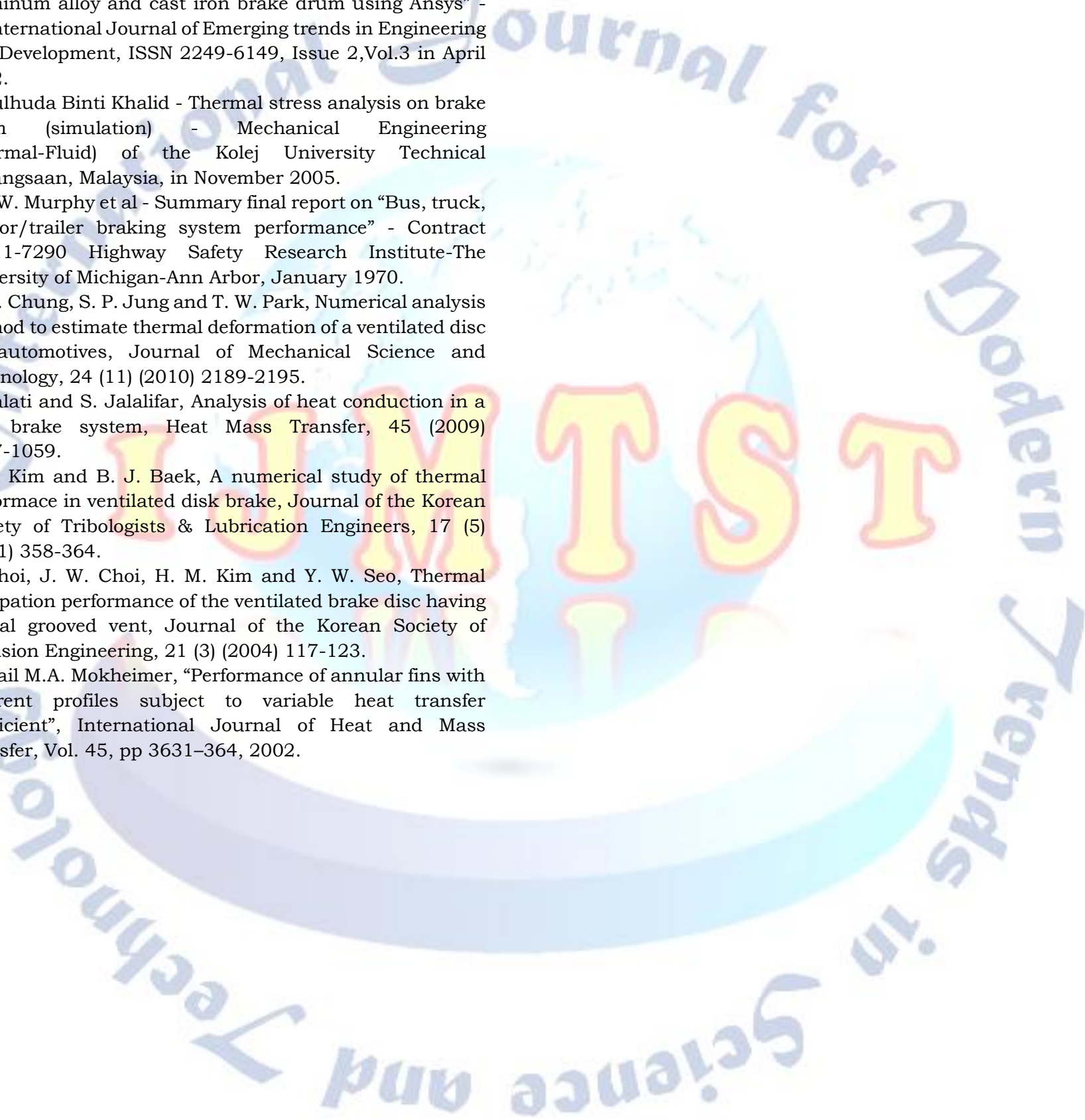